\title{
THE IMPLEMENTATION OF MIND MAPPING IN TARKIB LEARNING TO IMPROVE STUDENT LEARNING OUTCOMES
}

\author{
Dzurrotun Nafisah \\ Universitas Islam Negeri Maulana Malik Ibrahim Malang, Jawa Timur, Indonesia \\ Email: dzurrotunnafisah6931@gmail.com
}

\section{Rasmuin}

Universitas Islam Negeri Maulana Malik Ibrahim Malang, Jawa Timur, Indonesia Email: muin@uin-malang.ac.id

\section{DOI: 10.35445/alishlah.v11i2.151}

Accepted: October $19^{\text {th }}, 2019$. Approved: November $6^{\text {th }}, 2019$. Published: December $30^{\text {th }}, 2019$

\begin{abstract}
This study aims to determine the effect of using mind mapping techniques in tarkib learning.This type of research is a classroom action research using the Kemmis and MC Taggart models with two cycles and each cycle there are four stages must be carried out including planning, action, implementation, observation, and reflection.The subjects of this study were students of grade VII C Madrasah Tsanawiyah Negeri Batu, East Java.The instrument used in this research wereobservation, documentation, interview, and test. The technique of data analysis in this research is a descriptive analysis. The results showed that the use of mind mapping methods in tarkib learning can improve the completeness of student learning outcomes. This can be seen from the results of student learning in the first cycle only reached an average of 65.63, and increased in the second cycle with an average of 76.06 .
\end{abstract}

Keywords: Mind Mapping Method, Tarkib, Learning Outcomes 
Al-Ishlah: Jurnal Pendidikan - ISSN: 2087-949o (p); 2597-940X (e)

Vol. 11, No. 2 (2019)

\title{
PENERAPAN METODE MIND MAPPING DALAM PEMBELAJARAN TARKIB UNTUK MENINGKATKAN HASIL BELAJAR SISWA KELAS
}

\begin{abstract}
Abstrak
Penelitian ini bertujuan untuk mengetahui pengaruh penggunaan teknik mind mapping dalam pembelajaran tarkib. Jenis penelitian yang digunakanadalah penelitian tindakan kelas (PTK) menggunakan model Kemmis and MC Taggart dengan dua siklus dan masing-masing siklus ada empat tahapan yang harus dilakukan meliputi perencanaan, pelaksanaan tindakan, observasi, dan refleksi. Subjek penelitian ini adalahkelas VII C Madrasah Tsanawiyah Negeri Batu Jawa Timur. Instrumen yang digunakan pada penelitian ini meliputi observasi, dokumentasi,wawancara,dan juga tes tulis. Teknik analisis data yang digunakan dalam penelitian ini adalah menggunakan analisis deskriptif. Hasil penelitian menunjukkan bahwa penggunaan metode mind mapping dalam pembelajaran tarkib dapat meningkatkan ketuntasan hasil belajar siswa. Hal ini bisa dilihat dari hasil belajar siswa pada siklus I hanya mencapai rata-rata 65,63, dan meningkat pada siklus II dengan rata-rata 76,06.
\end{abstract}

Kata Kunci: Metode Mind Mapping, Tarkib, Hasil Belajar

\section{PENDAHULUAN}

Bahasa merupakan kemampuan pikir seseorang yang terdiri atas simbolsimbol yang digunakan sebagai alat komunikasi dalam kehidupan bermasyarakat. Bahasa memiliki kedudukan yang penting dalam kehidupan manusia. Karena dengan adanya bahasa, masing-masing individu dapat berkomunikasi antar sesama. Sehingga bahasa dapat mempermudah dalam kehidupan manusia. Belajar bahasa pada hakikatnya adalah belajar untuk berkomunikasi karena bahasa adalah alat komunikasi antara individu satu dengan individu lain. Oleh karena itu, pembelajaran bahasa diarahkan untuk meningkatkan kemampuan pelajar dalam berkomunikasi, baik lisan maupun tulis. Begitu juga dengan pembelajaran bahasa Arab yang di dalamnya terdapat empat keterampilan yang harus dikuasai serta tata kebahasaan yang harus dipahami.

Pembelajaran Bahasa Arab di Madrasah Tsanawiyah memiliki tujuan untuk mengembangkan dan meningkatkan keterampilan-keterampilan berbahasa yang ada empat yaitu, istima', kalam, qira'ah, dan kitabah. Selain itu, dalam pembelajaran Bahasa Arab tata bahasa atau tarkib juga penting untuk dipelajari,karena dengan mempelajari tarkib akan mempermudah dalam mempelajari keterampilan-keterampilan berbahasa. Penelitian ini memilih lokasi di Madrasah Tsanawiyah Negeri Kota Batu. Hal ini, disebabkan madrasah ini 
Al-Ishlah: Jurnal Pendidikan - ISSN: 2087-949o (p); 2597-940X (e)

Vol. 11, No. 2 (2019)

merupakan madrasah yang memiliki salah satu indikator visi yang mengarah pada penguasaan bahasa Arab bagi para siswanya, yaitu berkualitas dalam prestasi IPA dan Bahasa Arab. Oleh karena itu, pembelajaran bahasa Arab di sana sangat ditekankan.

Realitas yang terjadi di lapangan Bahasa Arab justru menjadi salah satu mata pelajaran yang tidak begitu disukai dan diperhatikan oleh siswa. Hal ini menyebabkan hasil belajar siswayang mampu mencapai kriteria ketuntasan minimal (KKM) masih relatif rendah. Observasi yang peneliti lakukan dilapangan memperoleh informasi bahwa proses pembelajaran Bahasa Arab yang dilakukan di MTs Negeri Kota Batu masih menggunakan metode konvensional, yaitu ceramah. Proses kegiatan belajar mengajar yang demikian menyebabkan siswa kurang aktif, menjadi cenderung pasif karena hanya mendengarkan hal yang disampaikan guru, kegiatan pembelajaran bersifat monoton dan membosankan sehingga pelajaran Bahasa Arab terasa sulit bagi para siswa.

Kondisi yang sedemikian rupa mendorong adanya penggunaan metode yang bervariasi untuk meningkatkan gairah belajar siswa. Salah satu metode yang bisa digunakan untuk meningkatkan minat siswa dalam pembelajaran serta meningkatkan kreativitas siswa adalah metode mind mapping. Menurut Tony Buzan, metode mind mapping merupakan cara yang paling mudah untuk memasukkan informasi ke dalam otak dan mengambil informasi itu ketika dibutuhkan (Darusman, 2014). Mind mapping adalah teknik grafis yang kuat yang memberikan kunci universal untuk membuka potensi otak. Penggunaan mind mapping ini menggunakan keterampilan kata, gambar, nomor, logika, warna, dan ruang kesadaran dalam satu cara unik yang kuat sehingga mampu mengoptimalkan fungsi otak kanan dan kiri secara bersamaan (Windura, 2013). Dengan demikian, hal itu dapat memberikan kebebasan kepada peserta didik untuk menjelajahi luas tidak terbatas dari otaknya. Meskipun begitu, tidak berarti bahwa mind mapping hanya cocok digunakan untuk peserta didik yang cenderung belajar visual saja. Akan tetapi, pada praktiknya, proses belajar selalu melibatkan ketiga aspek, yaitu visual, auditori, maupun kinestetik (Swadarma, 2013).

Metode mind mapping memiliki beberapa manfaat yang akan dapat diperoleh anak, yaitu membantu untuk berkonsentrasi (memusatkan perhatian) lebih baik dalam mengingat, melatih kemampuan berpikir kritis dan komunikatif, mengasah rasa ingin tahu, meningkatkan kecepatan berpikir mandiri, serta menghemat waktu sebaik mungkin (Olivia, 2018). Walaupun memiliki beberapa keunggulan di atas, bukan berarti metode ini tidak memiliki kelemahan sama sekali. Warseno mengungkapkan bahwa metode ini memiliki beberapa kelemahan, diantaranya hanya peserta didik yang aktif yang terlibat, tidak sepenuhnya murid belajar, dan hasil mind mapping siswa bervariasi sehingga guru 
Al-Ishlah: Jurnal Pendidikan - ISSN: 2087-949o (p); 2597-940X (e)

Vol. 11, No. 2 (2019)

akan kerepotan memeriksa mind mapping yang dihasilkan oleh siswa (Warseno, 2011).

Dari studi literatur yang peneliti lakukan terdapat beberapa karya ilmiah yang masih memiliki hubungan dengan tema penelitian ini, diantaranya penelitian oleh Endah dan Nasiruddin yang merupakan penelitian eksperimen dengan menggunakan desain penelitian control group pretest-posttest design. Kesimpulan dari penelitian ini adalah metode mind mapping dapat meningkatkan hasil belajar siswa. Hal ini diketahui dari peningkatan posttest kelas eksperimen yang mencapai 38,75 poin sedangkan kelas kontrol hanya 3,12 poin (Endah \& Nasiruddin, 2019). Penelitian selanjutnya ditemukan kesimpulan bahwa metode mind mapping mempunyai pengaruh yang signifikan dalam proses pembelajaran. Terdapat peningkatan hasil belajar siswa. Pada siklus pertama, tanpa menggunakan metode mind mapping diraih ketuntasan sebesar $61,90 \%$. Setelah siklus kedua yang menggunakan mind mapping meningkat menjadi 95,23\% (Susanti, 2016). Penelitian oleh Eny Djauharatun Nisak yang berjudul "Penerapan Metode Mind Mapping untuk Meningkatkan Hasil Belajar PKN pada Siswa Kelas IX SMPN 1 Kalidawir" menunjukkan adanya peningkatan hasil belajar siswa yang mencapai nilai KKM yang semula $52,9 \%$ pada siklus I menjadi $88,2 \%$ pada siklus II (Nisak, 2018).

Dari beberapa latar belakang di atas, maka peneliti menggunakan metode mind mapping dalam pembelajaran tarkib untuk meningkatkan hasil belajar siswa MTs Negeri Kota Batu Jawa Timur. Hal ini disebabkan tarkib merupakan hal yang sangat penting dalam pelajaran Bahasa Arab dan metode mind mapping telah terbukti memberikan hasil yang signifikan dalam upaya meningkatkan hasil belajar siswa.

\section{METODE PENELITIAN}

Penelitian ini dilaksanakan di MTs Negeri Kota Batu selama dua bulan yaitu bulan Agustus sampai dengan September 2019. Adapun subjek penelitiaannya adalah siswa kelas VII C MTs Negeri Kota Batu tahun pelajaran 2019 - 2020 dengan jumlah 33 siswa, seorang guru Bahasa Arab MTs Negeri Kota Batu, dan penelti. Penelitian ini termasuk jenis penelitian tindakan kelas (PTK) yang menggunakan model Kemmis and MC Taggart. Adapun tahapan yang harus dilaksanakan pada model ini adalah perencanaan, tindakan, dan pengamatan sebagai satu kesatuan, serta yang terakhir refleksi. Penelitian ini menggunakan model tersebut karena dalam tahapan tindakan dan observasi dilaksanakan pada waktu yang bersamaan, yaitu saat pembelajaran sedang 
Al-Ishlah: Jurnal Pendidikan - ISSN: 2087-949o (p); 2597-940X (e)

Vol. 11, No. 2 (2019)

berlangsung. Adapun gambar yang menunjukkan model penelitian tersebut adalah sebagai berikut.

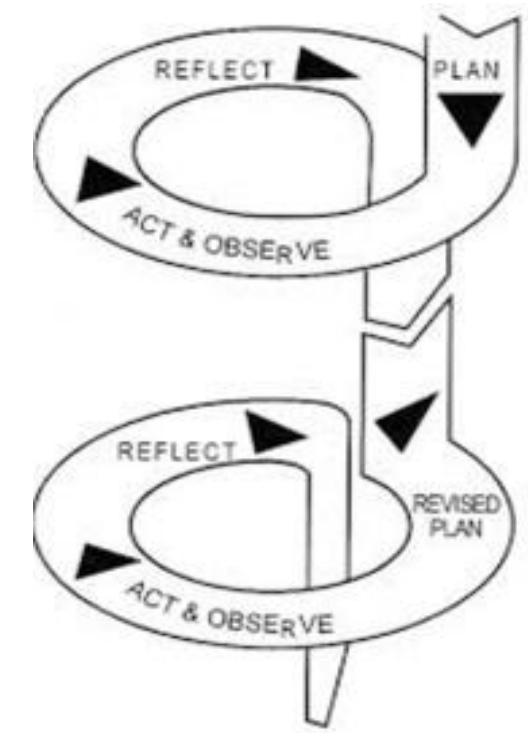

\section{Gambar 1 Siklus PTK Menurut Kemmis \& MC Taggart}

Tahapan penelitian ini terdiri atas empat kegiatan pada setiap siklusnya, yaitu sebagai berikut.

a. ProsesTindakan Siklus I

1. Perencanaan

Dalam tahapan perencanaan, guru perlu menyiapkan beberapa perangkat pembelajaran meliputi silabus, RPP, serta teknik dan instrumen penilaian.

2. Pelaksanaan Tindakan dan Observasi

Pada siklus pertama ini, siswa diberikan materi tarkib yaitu tentang mubtada' dan khabar. Dalam proses pembelajaran ini belum menggunakan metode mind mapping, tetapi menggunakan metode ceramah. Pelaksanaan tindakan ini juga bersamaan dengan dilaksanakannya observasi. Peneliti mengamati aktivitas siswa dan respons siswa dalam pembelajaran tarkib.

3. Refleksi

Proses terakhir adalah guru memberikan refleksi dengan cara pemberian tes tulis kepada siswa untuk dijadikan bahan dasar perbaikan pada siklus II. Kekurangan-kekurangan yang terjadi pada siklus I dapat diperbaiki. 
Al-Ishlah: Jurnal Pendidikan - ISSN: 2087-949o (p); 2597-940X (e)

Vol. 11, No. 2 (2019)

b. Proses Tindakan Siklus II

1. Perencanaan

Pada siklus II ini, perencanaan yang harus disiapkan masih tetap sama dengan siklus I, yaitu silabus, RPP, teknik penilaian, dan instrumen penilaian.

2. Tindakan dan Observasi

Pada siklus yang kedua ini, siswa diberikan materi tarkib yaitu tentang mubtada' dan khabar sebagaimana siklus pertama. Hanya saja, pada siklus yang kedua ini sudah digunakan metode mind mapping. Pelaksanaan tindakan ini juga bersamaan dengan dilaksanakannya observasi. Peneliti mengamati aktivitas dan respons siswa pada saat pembelajaran tarkib.

3. Refleksi

Refleksi pada tahap terakhir dari siklus kedua ini dilakukan melalui pelaksanaan tes tertulis kepada siswa. Adapun hasil tes dan observasi dapat dijadikan bahan dasar untuk pengolahan data.

Teknik pengambilan data pada penelitian ini menggunakan teknik tes dan non tes. Teknik tes dilaksanakan pada akhir siklus I dan siklus II dengan tujuan untuk mengukur pemahaman siswa terhadap materi tarkib dengan menggunakan metode mind mapping. Sementara, teknik nontes dilaksanakan pada saat pembelajaran sedang berlangsung, yaitu observasi aktivitas siswa. Observasi dilakukan dengan tujuan agar peneliti dapat mengetahui respons siswa terhadap pembelajaran tarkib Bahasa Arab. Selain observasi, wawancara juga dilaksanakan untuk mengetahui pendapat siswa mengenai pembelajaran tarkib Bahasa Arab, khususnya pada materi mubtada' dan khabar dengan menggunakan metode mind mapping. Sementara, untuk teknik analisis data dalam penelitian ini digunakan analisis deskriptif kualitatif dengan perhitungan nilai tes siswa.

\section{HASIL DAN PEMBAHASAN}

Mengacu pada hasil observasi dan tes siklus I terlihat masih rendahnya hasil belajar siswa. Ketika mengikuti proses kegiatan belajar mengajar Bahasa Arab, khususnya pembelajaran tarkib, minat dan motivasi siswa masih kurang. Hal tersebut terlihat dari nilai-nilai tes siswa yang masih belum bisa dikatakan tuntas atau belum mencapai target yang sudah ditentukan. Hasil dari siklus pertama ini dapat dijadikan sebagai patokan oleh guru untuk meningkatkan minat dan motivasi siswa pada siklus kedua sehingga hasil akhir proses dan hasil belajar Bahasa Arab khususnya tarkib, menjadi lebih baik. 
Al-Ishlah: Jurnal Pendidikan - ISSN: 2087-949o (p); 2597-940X (e)

Vol. 11, No. 2 (2019)

Peneliti mengambil kesimpulan bahwa prestasi belajar yang diperoleh siswa kelas VII C pada pembahasan tarkib masih cukup rendah mengacu pada tabel sebagai berikut.

Tabel 1 Nilai Ulangan Harian pada Siklus I dan II

\begin{tabular}{cccc}
\hline No & Uraian & Tes Siklus I & Tes Siklus II \\
\hline 1 & Nilai Terendah & 45 & 55 \\
2 & Nilai Tertinggi & 85 & 100 \\
3 & Nilai Rata-Rata & 63,63 & 76,06 \\
\hline
\end{tabular}

Tabel 2 Distribusi Frekuensi Nilai Tes pada Siklus I dan II

\begin{tabular}{ccc}
\hline \multirow{2}{*}{ Interval Nilai } & \multicolumn{2}{c}{ Frekuensi } \\
\cline { 2 - 3 } & Tes Siklus I & Tes Siklus II \\
\hline $41-50$ & 5 & 0 \\
$51-60$ & 10 & 5 \\
$61-70$ & 8 & 9 \\
$71-80$ & 7 & 11 \\
$81-90$ & 3 & 5 \\
$91-100$ & 0 & 3 \\
\hline
\end{tabular}

Dari tabel hasil tes pada siklus I dapat ditarik kesimpulan bahwa pembelajaran tarkib dengan menggunakan cara konvensional, yaitu menggunakan metode ceramah, menghasilkan nilai rata-rata siswa 63,6 dengan nilai terendah 45 dan nilai tertinggi 85.Pada nilai rata-rata tersebut masih banyak siswa yang belum mencapai kriteria ketuntasan minimal (KKM) dan masih harus ada perbaikan secara bertahap dalam proses pembelajarannya. Setelah dilaksanakan evaluasi pada siklus pertama, disusunlah pembelajaran siklus kedua dengan menggunakan metode mind mapping. Hasil belajar berdasarkan analisis data pada tabel diatas, pada siklus kedua diperoleh nilai paling rendah 55 dan nilai tertinggi 100 dengan nilai rata-rata siswa 76,01. Dari hasil analisis tersebut terlihat adanya peningkatan prestasi belajar siswa pada siklus II.

Selain dari kegiatan di atas, peneliti juga melaksanakan wawancara kepada beberapa siswa untuk menanyakan pendapat mereka tentang pembelajaran tarkib Bahasa Arab, khususnya pada materi mubtada' dan khabar menggunakan metode mind mapping. Dari hasil wawancara yang telah dilaksanakan oleh peneliti 
Al-Ishlah: Jurnal Pendidikan - ISSN: 2087-949o (p); 2597-940X (e)

Vol. 11, No. 2 (2019)

ditunjukkan bahwa 8 (delapan) dari 10 (sepuluh) siswa berpendapat pembelajaran menggunakan metode mind mapping menjadikan pembelajaran menjadi menyenangkan serta dapat menumbuhkan semangat dalam mempelajari Bahasa Arab, khususnya tarkib.

Dari proses dilaksanakannya siklus I dan II tersebut dapat dikatakan bahwa telah terjadi peningkatan kualitas pembelajaran yang telah dilakukan yang ditandai dengan adanya peningkatan keaktifan siswa dalam mengikuti pembelajaran serta adanya peningkatan hasil belajar. Pada pelaksanan siklus pertama, pembelajaran yang dilakukan secara konvensional dengan metode ceramah, suasana di dalam kelas tampak pasif. Guru hanya memberikan ceramah dalam menyampaikan materi sedangkan siswa mendengarkan. Sebagian ada yang berbicara dengan temannya dan tidak memperhatikan hal yang disampaikan guru. Pada pembelajaran siklus pertama ini kelas tampak begitu monoton sehingga semangat belajar dari siswa kurang.

Dari siklus pertama diperoleh data tentang hasil belajar siswa yang tuntas mencapai batas kriteria ketuntasan minimal (KKM) 70 hanya sebanyak 10 siswa atau sebesar 30,3\% dari jumlah siswa sebanyak 33 dengan rata-rata nilai sebesar 63,6. Hasil ini masih sangat jauh dari kata berhasil seningga perlu diadakannya desain ulang model pembelajaran dengan menggunakan metode yang mampu meningkatkan semangat siswa dalam mengikuti pembelajaran.

Berdasarkan pengalaman dari siklus pertama, pembelajaran pada siklus kedua dilaksanakan dengan menggunakan metode mind mapping. Dengan metode ini, proses pembelajaran tampak begitu hidup. Semua siswa melakukan aktivitas belajar tanpa ada yang berbicara sesama temannya. Suasana belajar tampak menyenangkan dilihat dari aktifnya siswa mengikuti langkah demi langkah yang harus dilalui.

Dari data yang ada, hasil belajar pada siklus kedua ini mengalami peningkatan yang cukup signifikan. Diperoleh data bahwa 27 siswa telah memperoleh hasil belajar yang mencapai KKM atau sebesar $81,8 \%$ dengan ratarata nilai mencapai 76,1 . Ada peningkatan sebanyak 51,5\% dari siklus pertama. Oleh karena itu, peneliti menyimpulkan bahwa pada siklus kedua ini metode mind mapping telah mampu meningkatkan hasil belajar siswa.

\section{SIMPULAN}

Berdasarkan penelitian yang telah dilakukan serta analisis datayang diperoleh dari kelas VII C MTs Negeri Kota Batu tahun pelajaran 2019-2020, dapat diambil kesimpulan bahwa pembelajaran tarkib Bahasa Arab menggunakan metode mind mapping dapat meningkatkan hasil belajar siswa. Hal tersebut 
Al-Ishlah: Jurnal Pendidikan - ISSN: 2087-949o (p); 2597-940X (e)

Vol. 11, No. 2 (2019)

terbukti dari hasil analisis data yang telah peneliti lakukan, yakni adanya peningkatan dari sebelumnya. Sebelum diberikan tindakan, nilai rata-rata siswa hanya mencapai 63,63 dengan persentase ketuntasan 30,3\%, sedangkan setelah diberikan tindakan nilai rata-rata siswa dapat mencapai angka 76,06 dengan persentase ketuntasan sebesar $81,8 \%$.

\section{DAFTAR PUSTAKA}

Darmadi, (2017). Pengembangan Model Dan Metode Pembelajaran Dalam Dinamika Belajar Siswa. Yogyakarta: Deepublish.

Darusman, R. (2014). Penerapan Metode Mind Mapping (Peta Pikiran) Untuk Meningkatkan Kemampuan Berpikir Kreatif Matematik Siswa Smp. Infinity Journal, 3(2).

Endah, \& Nasiruddin. (2019). Eksperimentasi Metode Mind Map pada Pembelajaran Nahwu Bahasa Arab untuk Meningkatkan Hasil Belajar Siswa. Al Mahara, 5(1).

Falah, Ahmad. (2014). Pembelajaran Bahasa Arab Berbasis Mind Map Untuk Meningkatkan Pemahaman Bahasa Arab Pada Tingkat Madrasah. Arabia $6(1)$.

Giyarto. (2014). Penerapan Model Problem Based Learning Untuk Meningkatkan Kemampuan Pemecahan Masalah Pada Mata Pelajaran PKN Di Kelas VII. A SMP Bina Utama Kecamatan Ulu Belu Kabupaten Tanggamus. Skripsi.

Nisak, E. D. (2018). Penerapan Metode Mind Mapping untuk Meningkatkan Hasil Belajar PKn Pada Siswa Kelas IX SMPN 1 Kalidawir. Briliant: Jurnal Riset Dan Konseptual, 3(1).

Panditaa. (2015), Metodologi Pengajaran Tata Bahasa Arab. Dikutip 12 September 2019 dari kumpulan makalah dan artikel : http://downloadmakalahdanartikel.blogspot.com/2015/04/metodologipengajaran-tata-bahasa-arab.html.

Olivia, F. (2018). Gembira Belajar Dengan Mind Mapping. Jakarta: Elex Media Computindo.

Rahmayanti, Ira Dwi Setya, and Henny Dwi Koeswanti. (2017). Penerapan Model Make a Match Untuk Meningkatkan Hasil Belajar Matematika 
Al-Ishlah: Jurnal Pendidikan - ISSN: 2087-949o (p); 2597-940X (e)

Vol. 11, No. 2 (2019)

Materi Siswa Kelas IV SD Negeri Diwak. UNION: Jurnal Ilmiah Pendidikan Matematika 5 (3).

Susanti, S. (2016). Metode Mind Mapping Untuk Meningkatkan Hasil Belajar IPS di Sekolah Dasar. Jurnal Guru Pendidikan Sekolah Dasar, 1(1).

Swadarma, D. (2013). Mind Mapping Dalam Kurikulum Pembelajaran. Jakarta: Elex Media Computindo.

Warseno, A. (2011). Super Learning. Yogyakarta: Diva Press.

Windura, S. (2013). 1st Mind Map Untuk Siswa, Guru Dan Orang Tua. Jakarta: Elex Media Computindo. 